\author{
Chichulina Kseniia \\ $\mathrm{PhD}$, Associate professor \\ Department of Economics, Entrepreneurship and Marketing \\ National University «Yuri Kondratyuk Poltava Polytechnic» \\ Poltava, Ukraine \\ ORCID 0000-0001-7448-0180 \\ Skryl Vitaliia \\ $\mathrm{PhD}$, Associate professor \\ Department of Finance, Banking and Taxation \\ National University «Yuri Kondratyuk Poltava Polytechnic» \\ Poltava, Ukraine \\ ORCID 0000-0003-4064-8146
}

\title{
FORMATION OF ENERGY SAVING POLICY FOR AGRICULTURAL ENTERPRISES ON THE BASIS OF EUROPEAN EXPERIENCE
}

\section{European experience of energy saving policy formation in agricultural enterprises}

The development of the Ukrainian economy largely depends on the solution of the problem of providing energy carriers. The insufficient volume of its own energy resources forces the Ukrainian government to make decisions on significant imports. Today, the world is trying to solve the problem of energy carriers on the basis of new approaches, which are based on: first, improving the technological process in terms of energy intensity of production; second, developing energy conservation; and third, expanding energy production through renewable sources. In economically developed countries, the share of energy produced from renewable sources is growing. Ukraine is an energy-deficient country that imports $75 \%$ of natural gas and $85 \%$ of oil and petroleum products. This structure of the fuel and energy balance is critical and unacceptable from the point of view of energy security.

Efficient use of energy is one of the integral indicators of the development of the economy, science and socio-cultural development of the nation. According to this indicator, Ukraine is among those States where the stagnation of the existing situation can provoke a serious economic crisis with subsequent large-scale social upheavals. One of the largest consumers of energy in the national economy is agricultural production. Thus, the agro-industrial complex of Ukraine consumes 35 million tons of conventional fuel per year, half of which is in the form of scarce liquid fuel. Therefore, in the coming years, it is necessary to improve the energy base of agricultural production, and first of all, to provide heat and energy for housing and communal needs. However, these tasks are still being solved without proper economic justification.

The experience of advanced foreign countries in energy saving is difficult to borrow, because energy and agriculture have developed behind other economic 
schemes, which means that the technological level of agricultural production is significantly lower than the world [1]. With regard to crop production, the following areas of economy and rational use of fuel and energy resources can be identified [2]:

1. Development and implementation of a system of measures to improve soil fertility and crop productivity.

2. Improvement, development and implementation of energy-saving production technologies.

3. Improving the management system by developing and implementing organizational, technical and economic measures that reduce losses and save oil products.

4. Development of normative-technological and methodological documentation for mechanized processes and technical means.

5. Improvement and development of new energy-saving equipment.

6. Use of non-traditional energy sources.

The first direction includes the preparation and improvement of fields, land reclamation, increasing soil fertility, introduction of high-yielding resistant varieties of crops, and seed preparation. This area is very important and requires a comprehensive solution, but the mechanization of work in it is not decisive. The second direction covers minimizing tillage, combining technological processes, transferring some technological processes to a hospital, replacing energy-intensive processes with less energy-intensive ones, and other measures. The third direction provides for optimizing the structure of acreage; optimizing the structure of machinetransport mechanisms; improving maintenance and repair of machine-transport mechanisms; rational aggregation of agricultural machinery; improving storage, transportation, refueling and accounting of petroleum products; improving the incentive system for employees to save oil products; rational organization of the use of machine-tractor units; improving the organization of cargo transportation [3].

The fourth direction covers standardization of the assessment of fuel and energy costs for technologies and technical means; development of standards for the consumption of petroleum products; development and implementation of methods for assessing fuel and energy costs in agricultural production technologies; development of methods for calculating the required amount of petroleum products at various levels. The fifth direction involves the creation of technical types of energy saving, namely engines with lower specific fuel consumption (up to $190 \ldots 200 \mathrm{~g} / \mathrm{kW} . \mathrm{h}$ ); increasing the share of production of crawler tractors; equipment for all tractors with devices for determining the optimal engine operating modes; introduction of computers to optimize engine operating modes; reducing the impact of propellers on the soil by using lowpressure tires and rubber-metal tracks; introduction of mobile power tools that run on gas and using alternative fuels; development of energy-saving equipment, improving the reliability of equipment, etc. Universalization of tractors can reduce 
energy consumption by $20 \ldots 25 \%$. The use of combined machine-tractor units will help to reduce energy consumption for soil preparation and sowing by $15 \ldots 20 \%$.

The sixth direction includes the use of solar energy, wind, heat from underground sources, and agricultural waste to produce biogas. This area also includes measures and projects to replace petroleum products with other types of fuel that are manufactured on the basis of crop production (alcohol, oil, and others) [3]. In the process of using the machine and tractor fleet, special attention should be paid to the second and third directions, which can be implemented directly in farms and provide up to $55 \%$ of the relative improvement in fuel efficiency. Analysis of factors and limits of changes in the proportions between economic growth and energy consumption confirm that now the driving force of energy saving in Ukraine is the transition to a resource - and energy-saving type of economic growth [5].

There are no sufficient own resources to cover energy-intensive production. It is impossible to solve the problem by increasing the exploitation of labor and actually reducing wages, since this will mean a narrowing and collapse of the domestic market, which creates conditions for bankruptcy. At the same time, stepby-step and consistent energy saving can save up to $1 / 3$ of energy resources. The saved funds can be used to update outdated technical base, develop new technologies, and raise the standard of living of the people.

There are no sufficient own resources to cover energy-intensive production. It is impossible to solve the problem by increasing the exploitation of labor and actually reducing wages, since this will mean a narrowing and collapse of the domestic market, which creates conditions for bankruptcy. At the same time, stepby-step and consistent energy saving can save up to $1 / 3$ of energy resources. The saved funds can be used to update outdated technical base, develop new technologies, and raise the standard of living of the people. Priority development of agriculture has always been one of the main economic tasks of the EU. Previously, this task was solved by implementing appropriate policies within individual States.

There are no sufficient own resources to cover energy-intensive production. It is impossible to solve the problem by increasing the exploitation of labor and actually reducing wages, since this will mean a narrowing and collapse of the domestic market, which creates conditions for bankruptcy. At the same time, stepby-step and consistent energy saving can save up to $1 / 3$ of energy resources. The saved funds can be used to update outdated technical base, develop new technologies, and raise the standard of living of the people.

Priority development of agriculture has always been one of the main economic tasks of the EU. Previously, this task was solved by implementing appropriate policies within individual States. The growing problem of energy and competition and strengthening the connection of politics with the economy has put the issue of energy security of the EU countries at the European level. Western politicians and businesses see the solution to the energy problem in strengthening 
integration processes in the sphere of energy supply for the economy and sociocultural sphere on a single organizational and legal basis. The creation of a panEuropean energy market was started in the $90 \mathrm{~s}$ with the adoption of relevant directives. The main documents regulating the new EU energy policy are the Energy Charter and the Energy Charter Treaty.

These documents pursued such strategic goals as strengthening the EU's energy security, increasing the competitiveness of the economy of the NATO countries, preventing the monopoly pressure of energy exporters on importers, improving the environment, and reducing energy prices.

Documents defining the General rules for the functioning of the domestic electricity and gas market, which were based on the unity of legal instruments, transparency of companies' activities in the energy market, free access to it for new participants, and prevention of monopolization. The EU's energy policy is developed by all EU governing bodies, but the main role is played by the European Commission. Operational issues are handled by the Directorate General for energy and transport. In 2003, at the initiative of the European Commission, new important decisions were adopted, which were enshrined in directives 2003/55/EC and 2003/54/EC. They define liberalization as the main means of optimizing the market, and broad access to the capital market with the supply of energy services and lower prices for such services as a promising goal of liberalization.

The documents defined the principles of market functioning that would ensure free competition, company development, and consumer interests. There were difficulties regarding the requirement to separate vertically integrated companies. In 2006, the so-called "Green book" was published, which outlines the main approaches to the essence of the new energy policy, its main tasks and means of solving these problems. The book highlights the need for a stable supply of energy to the EU from energy exporting countries, the importance of market liberalization, the need to save energy resources and develop new technologies in the energy sector, and the strengthening of environmental requirements for energy consumption. The EU's specific targets in the energy sector are to reduce energy supply by $13 \%$ by 2020 , bring the share of renewable energy sources to $20 \%$, and reduce carbon emissions by $20 \%$. In January 2007, an integrated package of actions was adopted to reform the energy sector and form a unified energy system [5].

The main tasks defined by the new document are infrastructure development, reducing the external vulnerability of the European Union countries, and combating negative climate change. The attitude towards nuclear power, which is now considered an important factor in enhancing energy security, is changing, and scientific research on the possibilities of using hydrogen as energy is being intensified. The legal, informational and organizational work carried out gave the experts reason to believe that the middle of 2007 was the time when the liberalization of the European Union market was formally completed. The formal reaction to the decision on further liberalization was more than positive - 13 States out of 27 opened 
their markets ahead of schedule. Relevant changes were also made to the legislation. However, it should be noted that there is a different vision of the essence of liberalization and the ways of its implementation among EU members.

Thus, in small countries where there are no super-powerful multinational companies, there were no reservations about the policy of liberalization. A different position was taken by countries such as Germany, France, and Italy, where powerful energy companies are built on the principle of vertically integrated [5].

These corporations did not accept the European Commission's demands to liquidate their structures as fair. They pre-empted new $\mathrm{m} \&$ a decisions by the stronger and the weaker, and thus defended their positions at the national level. In addition, they regarded the actions of the European Commission as discriminatory. There was a categorical disagreement with the intentions of European Union officials to achieve the separation of the transport sector from the production sector into an independent one. The long search for a compromise led to an adjustment of the energy policy. In September 2007 The European Commission submitted the socalled third energy package, adopted in April 2009, for consideration by EU members. The package included a number of legal acts, namely:

- Proposal for a Regulation of the European Parliament and of the Council establishing an Agency for the Cooperation of Energy Regulators);

- Proposal for a Directive of the European Parliament and of the Council amending Directive 2003/55/EC of the European Parliament and of the Council of 26 June 2003 concerning common rules for the internal market in natural gas;

- Proposal for a Directive of the European Parliament and of the Council amending Directive 2003/54/EC of 26 June 2003 concerning common rules for internal market in electricity;

- Proposal for a Regulation of the European Parliament and of the Council amending Regulation (EC) № 1775/2005 on conditions of access to the natural gas transmission networks;

- Proposal for a Regulation of the European Parliament and of the Council amending Regulation (EC) № 1228/2003 on conditions of access to the networks for cross-border exchanges in electricity.

The documents of the third package allow the "parent" company to keep the distribution network Manager under its control, provided that he is independent in management matters. An important aspect of the third package is the third-country regulation, which obliges foreign corporations that are admitted to the European distribution system to comply with the EU market rules. This means that the exporter will not be able to arbitrarily set prices in a particular country based on subjective wishes. However, this does not mean that the problems have been solved and there will not be a political, subjective or other factor in the European energy market. It is necessary to take into account that today in the European market, consumers actually enter into relations with the energy exporter at the level of national States [5]. It is necessary to take into account that today in the European 
market, consumers actually enter into relations with the energy exporter at the level of national States [5].

The issue of free choice of an external supplier is problematic in the current conditions. Thus, the EU's legislative activity in this area, without relying on real diversification, remains declarative. It should also be added that the EU's energy policy can be considered as having two vectors-internal and external. If there is a certain unity of understanding of energy problems and ways to solve them in the interaction of EU countries within the Union, there is no such unity in the understanding of the foreign economic strategy on energy issues. It is obvious that the current state of Affairs has developed according to the action of a number of reasons. First of all, it should be noted that the EU countries have different levels of energy supply with their own energy resources. If Norway and Denmark are relatively provided with primary energy sources, and Poland and the United Kingdom have significant reserves of coal, which reduces the severity of energy problems, then for such States as Austria or the Czech Republic, the import of energy resources is a matter of survival; secondly, European countries differ in their geographical location [5].

States located in the North of Europe require more energy resources. At the same time, they have limited opportunities to use solar energy. Southern countries consume less energy in the residential sector and have broader prospects for solar energy development. In addition, the geographical position of Maritime powers allows them to solve the issue of energy supplies, using a tanker fleet, which is denied to continental countries. The distance between countries and energy exporting countries is also different; third, EU countries differ in their structure and scale of production, which is also a factor in energy consumption. The level of production is also different, which means that the opportunities for energy efficiency are different; fourth, each of the countries formed its own energy balance based on established economic relations in this area with other countries. If, for example, Germany has five independent and sufficiently reliable sources of energy supply, the Czech Republic is limited to one; fifth, the mechanism for meeting energy needs in the EU is market relations and competition, for which regulatory policy is limited [5].

Based on the new energy policy, the EU attaches great importance to energy conservation. The importance of energy saving is explained by the fact that thanks to it, significant hydrocarbon resources are saved, consumers ' financial resources are saved, and carbon dioxide emissions are reduced.

In October 2016, the European Commission presented an updated energy saving action plan, which set strict energy efficiency standards for 23 product groups.

Special energy-saving controls relied on lighting devices for street and household use. The development and monitoring of plans to improve the energy efficiency of artificial lighting systems is entrusted to a special working group created in early 2007 - ROMS (Roll out Member States). 
Energy savings will also be facilitated by the introduction of new European lighting standards in the design of lighting installations: EN 12464-1 (Lighting of work places in premises); EN 15193-1 (energy assessment of buildings. Energy requirements for lighting-assessment of electricity needs for lighting). According to article 12 of the ESD (Energy Services Directive) The European Commission has delegated a mandate to the European Committee for standardization in electrical engineering (CENELEC) to develop special standards for energy conservation.

Such standards should provide for agreed methods for calculating the energy efficiency characteristics of buildings as a whole and of individual products, installations and systems in a complex of engineering equipment.

In December 2008, the European Commission decided to abandon incandescent lamps. According to the adopted document, light sources that consume a lot of electricity will be gradually replaced until September 2016. According to experts, such measures will reduce electricity consumption by 3-4 \%. The energy saved as a result of the introduction of new lighting devices in offices and residential areas will be enough to provide lighting for a country like Romania.

On December 9, 2008, the governments of the EU member States and the European Parliament adopted a bill on increasing the use of renewable energy sources by $20 \%$ until 2020 , reducing the use of electricity and greenhouse gas emissions by the same amount. The document provides for an increase in the share of biofuels in the EU energy sector to $10 \%$, as well as an increase in spending on research in the energy sector by $50 \%$. Energy saving programs are implemented by all EU countries. In this regard, the experience of those companies that have made the most progress in energy conservation is valuable [6].

Denmark is one of the European countries whose experience in energy saving is the most systematic and long-lasting. In the 60 s of the last century, the Danish economy experienced a significant recovery. The basis of the energy potential was oil and petroleum products, which accounted for almost $90 \%$. The energy crisis of the seventies and the sharp rise in prices for hydrocarbons forced the country's authorities to rethink state policy in the energy sector and make significant adjustments. The first step in this direction was the creation of a national energy supply planning system. The tasks of energy supply were solved in stages with the accumulation and use of the potential of the previous stages.

At the first stage, an energy plan was developed, which was put into effect in 1976. The main task of implementing this plan was to ensure a reliable power supply. The implementation of tasks envisaged implementation of measures for diversification of energy supply, creation of legislative base of energy supply, introduction of energy taxes, drawing up maps and schemes of power supply of certain areas of the country. In 1981, the second energy plan was put into effect, aimed at consolidating the results achieved and developing energy conservation. Taking into account high oil prices, state authorities are consistently reducing its 
share in the country's fuel balance, increasing the consumption of biogas, straw, wood shavings, household and agricultural waste, and agricultural waste heat. Practice has shown that combined heat and electricity production, as well as the use of district heating networks with high-tech thermal insulation, proved to be the most effective from an economic point of view.

Denmark is one of the leading countries in the world in terms of the share of Central heating. Almost all cities have Central heating, covering about $50 \%$ of Denmark's homes. In 1990, the third energy plan was adopted, which was a continuation of the previous stages and took into account the aggravation of environmental problems. Since the country's heat supply structure was currently well developed, the main efforts were focused on reducing carbon emissions into the atmosphere. This task is also being addressed at this stage within the European Union. The peculiarity of heat supply in Denmark is that the owners of the heat supply company through the municipality are all consumers who are connected and use the system. Due to this, the population is interested in improving the efficiency and reliability of heat utilities, as well as in reducing the price for providing services for thermal energy [6].

The realization of this goal is facilitated by the fact that consumers have wide opportunities to account for and regulate heat consumption, which in practice leads to significant savings in energy resources. It is also important to note that heat energy producers have the technological ability to switch from one type of energy consumption to another, depending on market conditions. This provides flexibility in the operation of the system, its reliability and economy. In addition, the presence of "peak" boilers in the heat supply system makes it possible to switch to a backup source in the event of accidents or any serious problems without disrupting the supply. From a technological point of view, the operation of heating networks in a relatively low temperature and pressure mode is of interest, which significantly reduces energy costs. The temperature of the direct-flow water is $80 \mathrm{C}$, the reverse flow is $4050 \mathrm{C}$. Denmark effectively forms its fuel and energy balance, with oil accounting for $43 \%$, gas for $24 \%$, coal for $21 \%$, and renewable energy sources for $12 \%$. Of the restorative energy sources, the use of wood sawdust is $44 \%$, wind energy is $27 \%$, straw burning is $27 \%$, and biogas production is $6 \%$.

In addition, geothermal installations and energy obtained from waste incineration are used. The effective use of electricity is facilitated by the existing ownership system in the industry. Power plants and infrastructure are controlled by companies that own power lines, as well as by major companies E2 and Elsam. Companies that distribute electricity are controlled by large and small groups of consumers, municipalities, and in some cases private investors [5]. Municipalities have large heating systems, while small ones are consumer associations organized on the model of cooperatives where consumers choose a Board of Directors. Such planning, according to the authorities, ensures a more rational use of energy. The 
state ably regulates the production of hydrocarbons. So, the extraction and processing of oil is performed by private companies, but the transport system is in state ownership.

The success of Denmark in the field of energy conservation is evidenced by the fact that having had a 50\% increase in agricultural production since 1970 , the country has not increased its energy consumption by a single percent during this period. Taking into account the worsening environmental situation, as well as trends in the global energy market, the Danish Ministry of transport and energy in 2005 developed a long-term strategy for the country's energy development for the period up to 2025. The beginning of energy saving in Germany was laid by the "law on priority of restoring energy", adopted in 1991. The task of improving energy efficiency in Germany is solved through the Ministry of the environment and partly the Ministry of economy, the Federal Ministry of transport, construction and urban development. Each of the ministries has its own tasks and corresponding powers [5].

The specifics of solving problems is that the focus is on specific aspects of the problem in the absence of such a separate document as the energy concept. At the same time, it should be noted that there is unity in General views on energy development. This unity takes place to reduce carbon dioxide emissions into the atmosphere, preserve the environment, develop renewable energy, strengthen the safety of existing nuclear power plants and prohibit the construction of new ones. According to existing views, specific work is being carried out to save energy and increase the energy efficiency of systems, machines, devices and mechanisms.

During the period 2000-2003, the German authorities invested at least 200 million euros annually in the development of renewable energy and energy saving. During 2003-2005, the funding for such projects was increased to 360 million euros. And since 2006, the growth of annual investment in renewable energy has become even more significant and amounted to about 1 billion euros.

The government actively attracts private capital to participate in new projects, using such means as organizing and conducting competitions for the implementation of energy-saving loans, providing tax incentives and obtaining loans. The German energy Agency (DENA) limited liability company, which is a Federal structure, takes an active position in conducting energy saving competitions. DENA's founders are the state and the credit Agency for renewal and development (KfW).

The Agency is engaged in a wide range of tasks such as monitoring energy consumption, analyzing the country's fuel and energy balance and the dynamics of energy prices, developing a strategy for the construction of electric installations using renewable energy sources, planning the modernization of existing power plants, trading emission quotas, organizing joint implementation of the latest projects, advising authorities on the effective use of energy, conducting active advocacy and explanatory work among the population. Wind power and the use of solar energy are becoming widespread in the country [7]. 
In Germany, solar power plants produce more than 3000 million $\mathrm{kWh}$ of electricity annually. In Berlin, it is planned to switch all swimming pools to solar energy. Private investors are given the opportunity to place more than 100,000 square meters on the roofs of public buildings. install solar panels and feed the resulting energy to the city grid. Since 2007, the Berlin administration has been buying only cars with reduced gasoline consumption in urban transport mode for its needs. Electrical appliances and equipment are marked depending on the level of energy consumption.

The procedure for gradually replacing the use of devices and equipment that have a level of expenditure within the established standards is defined. Germany is one of the countries of the European Union where modern energy saving technologies and alternative energy sources of solar energy, wind energy are most actively used. Poland has been implementing an energy saving system since 1991 . On several points of the energy saving policy of this country, it is worth dwelling. First of all, it should be noted that the Polish authorities have harmonized national legislation with EU legal documents. There are practically no contradictions between national and local legal acts [7].

The institutional and organizational support of the energy saving policy is being successfully formed. The country has established effective and purposeful work of state and local authorities, financial and commercial structures, business entities to carry out energy saving measures in the residential sector, the effective use of local resources and electricity, the introduction of solar energy, biogas production, waste disposal, heat and electricity generation from the burning of straw and other plant waste. Poland has a positive experience of mixed financing of energy projects (funds from the European Union, international donor funds, environmental funds, and the budget), where the system of tax incentives is skillfully used. The government is trying to use state levers to expand the range of creditors for such energy-saving measures, which require significant funds and are designed for the long term.

In Poland, there is a special communal Fund, the funds of which are accumulated through fees from the population and are used for implementing lowcost energy saving projects, improving the quality of heating, and current repairs. Energy consumption is based on signing and fulfilling the terms of the contract [8].

This allows you to avoid red tape associated with the licensing system, prevent monopolization of the sphere, improve the quality of services through competition, reduce prices and simplify audit. Energy saving policies of other countries are also of interest. In particular, the Netherlands is one of the leaders in the development of wind energy and energy using biofuels. Significant advances have been made in the development of cogeneration systems and heat pumps. Great Britain adjusts its energy policy, directing it on the one hand to the economical use of energy, on the other, to increase the efficiency of energy supply. In order to improve the country's energy supply, a decision was made in mid-2008 to unfreeze its nuclear 
energy development program. The first step in resolving this issue was an agreement with the French company Electricite de France SA to acquire British Energy, which produces up to $30 \%$ of all electricity in England and Scotland.

With the completion of the deal, the French company will begin construction of new nuclear power plants in the UK.

Sweden's experience in passive energy conservation is also valuable. It is believed that passive energy saving will make it possible to reduce energy consumption for heating by a third. In the Swedish city of Brogaden, a passive conservation project is being completed, where municipal apartment buildings built in 1970 and listed for major repairs are being reconstructed. The project is funded by the Swedish energy Agency and is implemented as part of a $20 \%$ reduction in energy consumption. The EU has achieved some success in optimizing relations within the Alliance on the issue of energy security. Legal instruments have been developed and put into effect to improve the energy climate in Western, Central and South-Eastern Europe. At the same time, the existing differences between the EU States do not allow this organization to pursue a single, comprehensive energy policy, especially in relations with energy exporters.

In these circumstances, energy policy may be limited and only concern issues related to further optimization of energy supply within the Union: infrastructure development; optimization of pricing policy; setting regional energy consumption standards in housing and utilities, transport; creating energy-efficient and energysaving consumer appliances; developing new, more efficient energy sources. The policy of saving energy resources in the market conditions will stimulate energyefficient policies in industrial and agricultural production [8]. A single comprehensive energy policy of the EU is possible only in the conditions of functioning of the economies not as national, but as a single economy of the Alliance, as a superpower with all the consequences for the functioning of the financial system, tax collection, formation of the annual budget for unification in General, regions, territories and cities in particular, restrictions on the activities of monopolies. A certain step in this direction is the creation of a unified electric power system.

The energy policy of the EU countries in the field of energy saving is proving to be effective and therefore should be used by our state. Implementation of energy saving programs requires changing the algorithm of work in the organizational, financial, legal and information spheres. Energy policy in the state should be based on the need to ensure the reliability of energy supply and its availability for the citizens of the country. The imbalance of these principles inevitably leads to the collapse of the entire policy.

Organizational energy saving can be implemented if the consumer is directly interested in the efficient use of energy. This interest is best shown when the energy consumer can influence energy saving elements (heat generating stations, heating networks, buildings). This requires optimizing the ownership system, for example, in Denmark. Effective energy conservation occurs when a 
country has an effective body that develops energy policy, advises the government, develops legal documents, monitors their implementation, and assists firms and individuals in implementing energy-efficient work. Germany has the best experience in this regard [5].

Currently, the EU countries have achieved significant results in energy conservation policy, it has become rational, socially-oriented and progressive. The introduction of numerous innovative projects in the field of energy conservation and the transition to the use of renewable energy occurred mainly due to the following principles:

1. Compliance with system approaches. It is worth noting that the energy saving policy is a separate important functional component of the state economic, industrial and social policy. Energy-saving measures are systemically interoperable (awareness-raising companies, financial mechanisms for implementing energysaving projects, regulatory and regulatory acts and state standards on energy conservation, voluntary agreements between the public, private and public sectors).

2. There is a General energy saving strategy. Most EU countries have detailed programs for implementing energy conservation policies that define specific goals and methods for achieving them. Some European States carry out functional inspections and systematically review their energy-saving programs. Moreover, many of them have special framework legislation regulating energy conservation. However, in most Central European countries such programs are only being developed, although there is already an awareness of the need to implement effective energy-saving policies.

3. Effective pricing policy. Almost all countries of Central and Eastern Europe, including Ukraine, have not yet implemented pricing reforms in the field of agricultural energy. In most of them, energy prices do not reflect the real market cost, so there is an acute problem of non-payment. In the EU countries, pricing policy is based on market principles, while it contains a flexible system for stimulating energy saving. In addition, there are also special "green" tariffs for electricity that is generated from renewable sources. 4. Effective institutional policy. In the EU member States, most energy conservation bodies operate as government bodies or departments of a Ministry. Such bodies have an extensive regional infrastructure, are provided with appropriate state financial and resource support and an appropriate legislative and regulatory framework.

5. Efficiency of energy saving policy. The introduction of energy-saving policies in the EU countries during the 70-90 years of the twentieth century made it possible to reduce the growth rate of energy consumption and significantly reduce the energy intensity of the GDP of European countries. This was achieved through the use of mainly market mechanisms, effective pricing policy, and modernization of basic energy-consuming technologies and equipment [9]. 


\section{Energy saving in the system of management of development of agricultural enterprises}

Agriculture is a complex of technologically and organizationally interconnected industries that together form a balanced, integrated and structurally complete system, the functional component structure of which is subordinated to a stable increase in food production of agriculture and animal husbandry. Each branch of agricultural production is a set of enterprises that produce certain types of homogeneous products or provide services that meet certain needs of the population in food, and industry-in raw materials [10].

In recent years, agricultural production has undergone great deformations. The transition from a planned to a market economy, the reform of collective and state farms, the development of new economic structures, deindustrialization, disincentives and especially agricultural production, reduction of agricultural means of production and objects of labor, excessive increase of prices, violation of material maintenance of farms, the destruction of agrochemical service, the absence of agrochemical service has reduced the productivity of the economic efficiency of the agro-resource potential and a decrease in the production of gross output of agriculture [6].

Agriculture is one of the most important branches of the economic complex of Ukraine, which plays an important role in strengthening the economy of our country, improving the living standards of the population and solving socioeconomic problems. However, the level of development of its productive forces significantly lags behind the national economic problems. The country does not yet produce enough grain, sugar beets, potatoes, vegetables, fruits, berries, grapes, meat, milk, eggs and other products. Therefore, the problem of accelerated development of agricultural production and stable growth of its products is gaining particular importance [10].

According to statistical data for 2017 [11] agriculture of Ukraine provides $8.2 \%$ of gross value added, employs more than 3 million people, uses fixed assets worth more than 100 billion UAH, operates almost 56.5 thousand economic entities using 21.6 million hectares of agricultural land. Produced in agriculture, 1 hryvnia of products allows you to get more than 12 hryvnia of products in other industries. Rural areas are a place for improving the health of the country's inhabitants, and the rural population is a talisman of national customs and traditions. Agricultural enterprises produce $44.9 \%$ of gross agricultural output, including $45.1 \%$ of crop production and $44.7 \%$ of livestock production. Farms of the population produce most of the gross agricultural output-55.1\%, including crop production- $54.9 \%$, livestock-55.3\%. In the structure of production, crop production makes up $58.4 \%$, livestock production- $41.6 \%$.

The leading place in the production of agricultural products is occupied by Poltava region. Although it occupies the 7th place in Ukraine, it also occupies the 3rd place in terms of gross agricultural production. The population is 
1445,0 thousand people, including urban-894 thousand people $(62 \%)$, rural 551 thousand people (38\%) [11].

Low profitability of production hinders its modernization, introduction of new technologies, updating of material and technical base. Investments in the development of the social sphere of the village now amount to only 7.6 billion $\mathrm{UAH}$, which is much lower than the need for them. As a result, the quantitative and qualitative characteristics of demographic processes in rural areas are deteriorating.

The development of production will require more and more energy resources, which makes the issue of energy conservation and energy efficiency extremely relevant. Therefore, it is necessary to introduce a comprehensive energy saving policy at the enterprise.

Complex energy saving is understood as a comprehensive coverage of economically justified technically achievable energy saving and energy efficiency measures that contain costly, low-cost and organizational measures aimed at maximizing the potential of energy saving. It is mandatory to implement integrated energy saving, use alternative energy sources, diversify and optimize energy supply, use modern science and technology to reduce the environmental burden on the environment, which will lead to economic growth of the enterprise. To determine the potential of energy saving and the impact of energy saving policy on the development of an agricultural enterprise, the first step is to form a scheme of energy consumption of the enterprise and determine the directions of energy saving potential formation (figure 1).

Under the development of the enterprise, we consider the process of natural change, the transition from one state to another, more perfect; the transition from the old qualitative state to the new, from simple to complex, from lower to higher; the degree of consciousness, enlightenment, culture. In [12] propose to define enterprise development as a long-term set of processes of quantitative and qualitative changes in the enterprise that lead to the improvement of his condition by increasing the potential of enterprise, adaptation to the external environment and internal integration, thereby increasing the ability of the company to counter the negative effects of the environment and its vitality.

The development of the agricultural enterprise will be considered as a set of long-term quantitative and qualitative changes, which lead to an increase in demand for products, increasing organized at all structural levels, the growth of the scale of activity of the enterprise, improve product quality and environmental friendliness of production, increase the competitive potential of the enterprise, the ability to resist negative external influences and economic stability in General. First of all, energy saving is the basis for increasing the potential of the enterprise, the ability to counteract negative manifestations of the external environment, and improving the quality of products and working conditions of employees. 


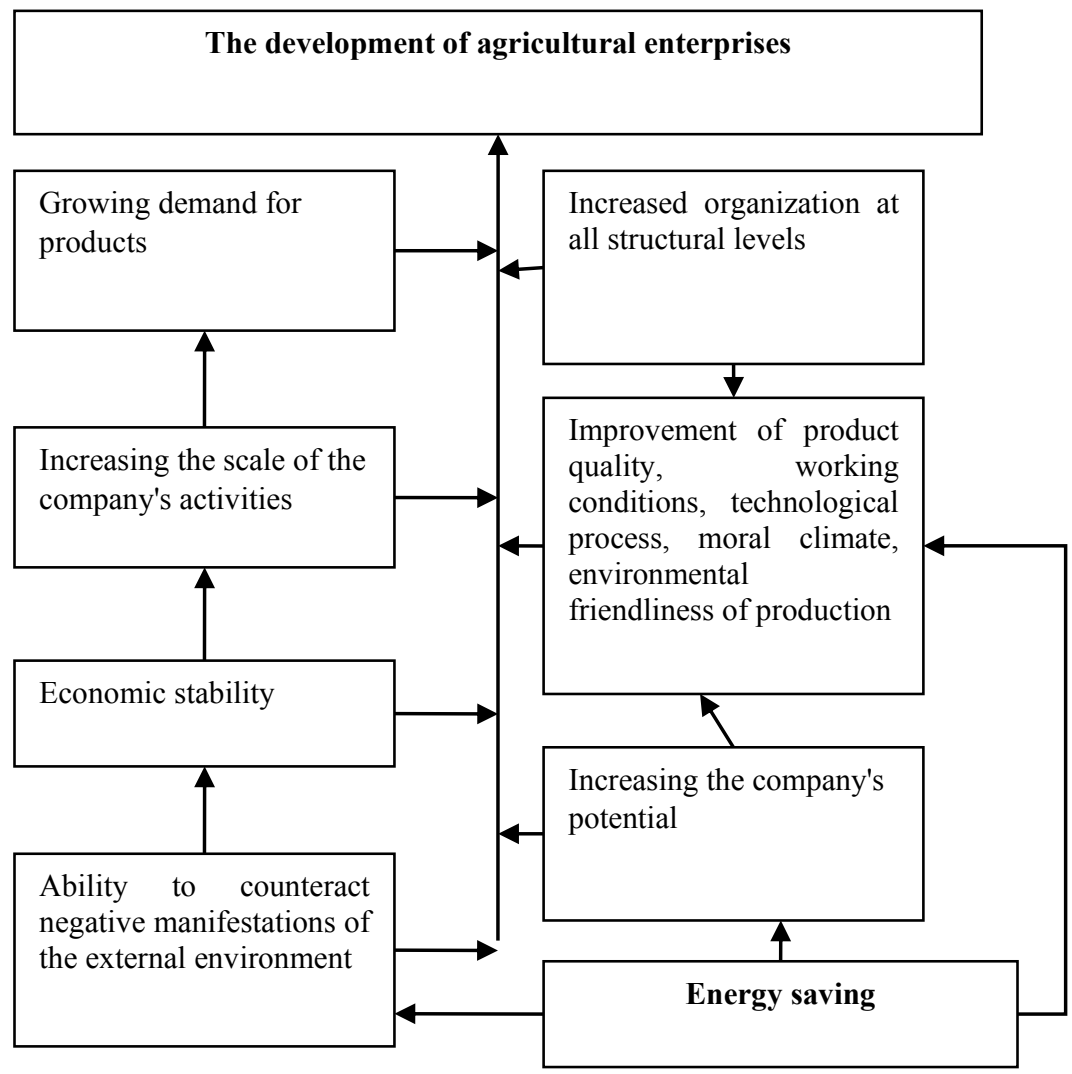

Fig. 1 - The scheme of development of the enterprise and the role energy saving in it

In turn, these factors lead to economic stability, increased organization, growth in the scale of enterprise activity and demand for products. The development of the enterprise should be based primarily on energy development. The formation of an energy development plan of the enterprise as a component of the overall development plan of the enterprise is shown in figure 2.

The priority direction of energy development of agricultural enterprises is the choice of investment solutions, sources of financing and the cost of capital. Investment decisions can be aimed at updating existing equipment and technological elements of the enterprise or at their modernization. Usually, upgrades will require significantly more money than upgrades, so the vast majority of investment decisions are aimed at upgrading. Modernization refers to improving properties, replacing individual components, increasing energy efficiency, and other positive changes in the objects of modernization. 


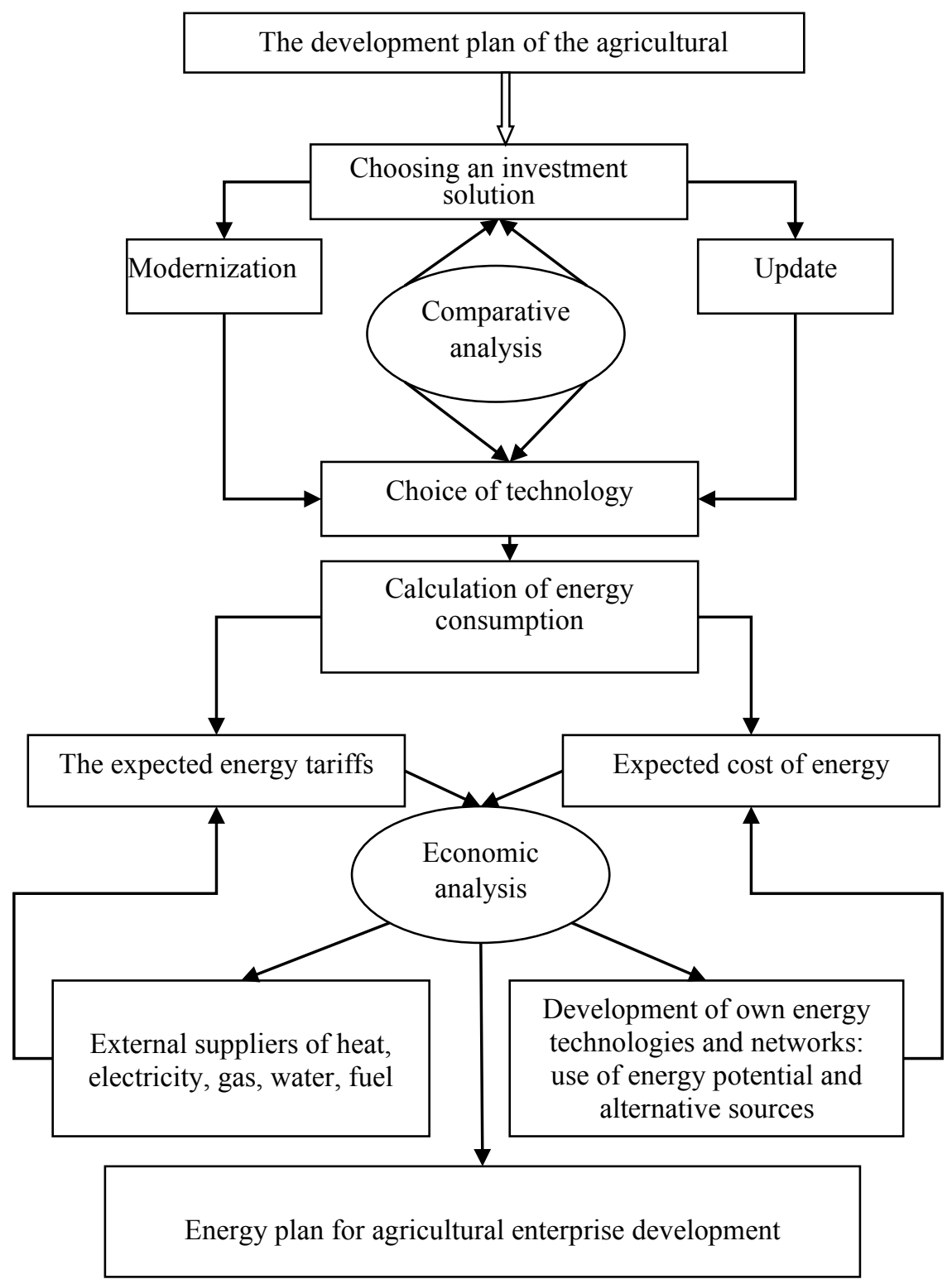

Fig. 2 - Formation of an energy plan for the development of an agricultural enterprise 
On the basis of comparative analysis, the choice of energy development technologies is made and energy consumption is calculated, after a set of energysaving actions is carried out. Based on the expected (projected) values of energy resources obtained from the energy potential and energy saving potential and projected energy tariffs from third-party suppliers, economic analysis and modeling is performed. Economic analysis allows you to clarify the cost of energy resources and energy tariffs, taking into account all possible consequences of investing in energy conservation. The result of refined calculations and economic analysis is a plan for energy development of the enterprise, which consists of a set of actions of organizational, economic and technical-technological directions aimed at implementing the energy saving policy at the industrial enterprise.

The energy development plan of the enterprise is the basis for the formation of an organizational and economic mechanism for energy saving [7].

You can imagine a typical scheme of energy consumption of a powerful agricultural enterprise. The main sources of energy resources (heat, fuel, electric energy, gas) are the fuel supply system (pipelines, tanks, warehouses for storing solid fuel), the gas supply system (pipelines, automation devices, compressor stations, storage tanks), water intake (pumping stations, pipelines, facilities for improving water quality), the power supply system (power lines, transformer stations). Conversion units - thermal power plants, boilers, compressor stations, gas distribution stations, converting energy and oil into convenient forms for consumption.

A number of transformations occur with the energy and resources that enter the territory of the enterprise: changes in form, condition, accumulation, distribution, losses and hits to the final consumers. After using the heat resources in the form of waste air, water, and gases, they pass through the recycling plants and partially return to the power supply system. The energy balance is made up in a material and synthetic form. The synthetic balance in conventional fuel allows us to determine the ways of energy saving and the direction of replacing some types of fuel with others [13].

For the analysis of material and synthetic balances, a graph of energy flows is formed, the centers of consumption, generation and losses are determined. the Initial information for the formation of balances is contained in the following documentation of the enterprise: forms of statistical reporting; norms of specific expenditures of heat, fuel and electric energy for production; in design, technical and operational documentation; energy passport of the enterprise; load schedules; instructions of the energy conservation inspection; reports on energy audits; documents on energy-saving measures and long-term development plans of the enterprise.

Given the interchangeability of various energy resources, it is necessary to pay attention to the formation of the energy balance, in which the cash flows are shown (table 1). The purpose of creating an energy balance is to determine the indicators of energy intensity of products, the amount of losses, the energy dependence of the enterprise, the potential for emissions and the balance of 
payments of subagents. The cost of fuel and resources is determined taking into account transport costs, travel losses and the cost of storage at the enterprise, provided that these areas are used for other needs. The second part of the balance allows to estimate energy and resource intensity of production, the cost of maintenance of buildings and grounds, assess the component of normative losses of energy are transferred to component of production costs [14].

The development of the enterprise as a process of transition to a more perfect state is impossible without reducing energy consumption, using the energy potential of emissions and improving the environmental situation by reducing the man-made load. The state of the energy system of an agricultural enterprise is directly related to its financial condition. The main reasons for imperfect energy consumption can be called obsolescence and low load of equipment, high energy intensity of production. Given the significant share of energy saving potential, it can be argued that the development of the enterprise is impossible without the introduction of energy-efficient solutions. Analysis of the implementation of energy saving measures can be evaluated by determining the efficiency of the use of fuel and energy resources.

Special attention should be given to energy-saving measures that involve the use of energy-saving potential, the energy potential of the enterprise through the introduction of low-cost and organizational solutions [15].

Table 1 - Energy Finance balance of an agricultural enterprise

\begin{tabular}{|l|l|}
\hline THE COST OF ENERGY RESOURCES & $\begin{array}{l}\text { THE COST OF ENERGY } \\
\text { RECEIVED BY THE ENTERPRISE, } \\
\text { RESOURCES } \\
\text { TRANSFERRED } \\
\text { PRODUCTS, UAH. }\end{array}$ \\
\hline $\begin{array}{l}\text { 1. The cost of fuel and resources: coal; } \\
\text { gas; mineral oils; water; electric energy; } \\
\text { masut; firewood; peat fuel briquettes, etc. }\end{array}$ & $\begin{array}{l}\text { 1. The cost of fuel, energy and } \\
\text { resources are transferred to the } \\
\text { cost of production }\end{array}$ \\
\hline $\begin{array}{l}\text { 2. Cost of energy resources supplied from } \\
\text { outside: electrical energy; heat energy. } \\
\text { resources spent on utilities and } \\
\text { are not transferred to the cost of } \\
\text { production }\end{array}$ \\
\hline $\begin{array}{l}\text { 3. Cost of fuel waste disposal: utilization } \\
\text { of slags and ash; payment for gas } \\
\text { emissions; payment for waste water. }\end{array}$ & $\begin{array}{l}\text { 3. The cost of regulatory losses } \\
\text { that are transferred to the cost of } \\
\text { production. }\end{array}$ \\
\hline 4. Debt of subagents & 4. Payments by subagents \\
\hline $\begin{array}{l}\text { 5. The debt for the previously received } \\
\text { energy }\end{array}$ & $\begin{array}{l}\text { 5. Cost of the enterprise's energy } \\
\text { saving potential }\end{array}$ \\
\hline TOTAL: UAH. & TOTAL: UAH. \\
\hline
\end{tabular}


Special attention should be given to energy-saving measures that involve the use of energy-saving potential, the energy potential of the enterprise through the introduction of low-cost and organizational solutions [15]. The main energy reserves of an agricultural enterprise are:

- reducing energy consumption by improving enterprise management, reducing the energy intensity of raw material processing, improving the quality of fuel and raw materials, improving and optimizing the technological process;

- replacing traditional energy sources with alternative or cheaper local fuels;

- using the potential of thermal emissions, flue gases, waste water, solid waste; generating energy using heat pumps, solar collectors, biogas plants;

- increase of the fuel and energy efficiency coefficient; replacement and modernization of equipment, thermal insulation of equipment, buildings and networks, replacement of lighting devices with energy-saving ones, automation and mechanization of labor, advanced training of production workers.

A separate organizational direction of energy saving is the creation of an energy management service at the enterprise. According to [16]: energy management is a management system based on standard measurements and checks that ensure the operation of an object that consumes only the amount of energy that is absolutely necessary for production. The chief energy Manager appointed by the company's management forms the structure of the energy management service, which performs such duties:

- monitoring and accounting of energy consumption;

- assistance in conducting an energy survey of an enterprise; implementation of energy saving measures;

- monitoring compliance with the company's energy efficiency policy;

- formation of incentive and motivational bases for employees of the enterprise in the issue of reducing resource consumption;

- training of the company's personnel in energy saving measures;

- monitoring of modern achievements of science and technology and new legislation in the field of energy saving.

The company's dependence on monopolistic energy suppliers leads to an increase in the risks of production activities. The enterprise is obliged to receive energy at the prices and quality imposed on it by a monopolistic supplier. Reducing energy consumption, diversifying energy supply sources, and reserving energy resources reduces the risks associated with energy supply. The introduction of energy-saving technologies will reduce the volume and probability of losses in production, the value of the effect obtained from reducing the risk of losses can be calculated according to equation 1 [7]:

$$
E=\sum_{i=1}^{n}\left(m_{0 i}-m_{1 i}\right) \times \theta \times P_{i}+\sum_{i=1}^{n}\left(H_{1 i}-H_{0 i}\right) \times\left(1+\left(O_{1 i}-O_{0 i}\right)\right),
$$


where $E$ is the effect of implemented energy saving technologies, UAH;

$n$ is the number of types of energy resources, the volume of which varies from energy saving measures

$m_{0 i}, m_{1 i}$ are energy intensity of $1 \mathrm{UAH}$ of produced products for the i-th type of energy resource before and after the implementation of the event, one / UAH; $\mathrm{UAH}$

$\theta$ is the volume of products produced after the implementation of the event,

$P_{i}$ is the unit price of the I-th type of energy resource, UAH;

$H_{i}$ is the probability of occurrence of risks and energy resources of the enterprise, share;

$O_{i}$ is the volume of losses from risks and those energy resources of the enterprise, UAH.

The introduction of energy saving measures will allow the company to get a number of positive effects, which have a significant role in the development of the enterprise. Energy saving measures lead to reduction of consumption of energy resources, reduction of fixed costs by enterprise, which ultimately will lead to an increase in profitability, decrease in costs of purchase of energy and environmental payments for polluting emissions.

Taking into account the features of two-part tariffs for heat supply, the enterprise, reducing the consumption of energy resources, can revise the terms of the contract with the heat distribution organization and reduce payments for the conditional constant component of the tariff.

\section{Methodological bases for evaluating the effectiveness of investments in energy-saving measures of agricultural enterprises}

In the context of the growing cost of energy carriers and the significant energy intensity of modern production, the problem of energy conservation and the choice of priority areas for investment in projects to improve the energy efficiency of enterprises is acute. One of the most important ways to effectively compete and increase the profitability of an enterprise in modern conditions is to reduce the cost of production. The process of energy saving should be evaluated comprehensively, taking into account all the consequences of investment: economic, technical, environmental, organizational, commercial and others. Analysis of the effectiveness of energy-saving measures is performed in order to determine its feasibility or to select the best event. This is due to the fact that energy-saving measures require investment, which is usually quite significant. In addition, the effectiveness of energy-saving measures is evaluated by a number of financial indicators of the enterprise, in particular, the cost price.

The choice of priority energy-saving means for improving the energy efficiency of an enterprise is a complex multiple task that requires effective evaluation criteria. 
Due to the fact that a modern industrial enterprise is usually limited in funds, there is a need to model the consequences of investment and a detailed justification of each selection criterion. Modern literature sources allow you to choose the necessary methods for calculating economic efficiency, but do not cover all the evaluation criteria for the analysis. The issue of evaluating economic, organizational, production, technical and environmental criteria in aggregate, as well as alternative comparison of investment in other investment projects, has not been sufficiently studied. This is why the criteria for selecting energy-saving investment projects and improving the methodology for determining the effectiveness of energy-saving measures require further research [15].

The set of criteria for selecting energy-saving measures should be classified as follows: economic, technical, industrial, environmental and organizational. The first step in comparison is the economic criterion. Initial capital expenditures, financial results of the project, and operating expenses for the implementation of this project for a certain period of time (credit and equity contributions, taxes) are the initial data that characterize the investment process [17]. Forecasting of financial results is usually carried out, focusing on the three basic development scenarios: optimistic, realistic and pessimistic.

An optimistic development scenario will be determined by the maximum profit from its implementation, while a pessimistic one will be determined by the minimum. The most uncertain development is a realistic project. By time factor: static, in which cash flows arising in different time periods are classified as equivalent, and dynamic cash flows for comparison using discounting or accrual. In absolute factors estimated absolute value of the profit obtained from the investment process; in relative factors are characterized by financial results from implementing them in the aggregate cost of the implementation process; time - are to a certain period of time. By the type of generalizing indicator - absolute, relative, and temporary.

Projects are also divided into those that are implemented in conditions of absolute certainty and uncertainty. The economic criterion is to find optimal sources of financing for energy-saving projects. The most common economic criteria include:

- net present value $(N P V)$;

- net cost of the terminal (NTV);

- return on investment index $(P I)$;

- internal rate of return $(I R R)$;

- modified internal rate of return $(M I R R)$;

- discounted return on investment $(D P P)$;

- payback period $(P P)$;

- the coefficient of efficiency of investments $(A R R)$;

- present value;

- annuity method;

- capitalized income;

- full economic result of the project $(P R j)[18]$. 
The summary indicator of the economic efficiency of energy-saving measures $E_{f}$ at the enterprise, for example, can be defined as:

$$
E_{f}=\left(\frac{V_{0} \times C_{0}}{S o} / \frac{V_{1} \times C_{1}}{S_{1}}-1\right) \times 100 \%,
$$

where $V_{0}, V_{1}$ are production volumes of the same type of products before and after energy modernization;

$C_{0}, C_{1}$ are unit prices before and after upgrading;

So, $S_{1}$ are costs of production.

With a constant product price and constant production volumes, the overall indicator of the economic efficiency of energy-saving measures will be determined only as the ratio of production costs before and after modernization.

According to the main criterion for comparing independent and alternative energy - saving projects is $N V P$-net present income, which is determined based on the number of projects, their interdependence and the availability of financial restrictions.

The simple payback period $T$ is determined by the formula:

$$
T=\frac{C}{E}
$$

where $E$ is the savings received from the implementation of activities, $\mathrm{UAH}$;

$C$ is the cost of implementing energy-saving measures in UAH.

This method is based on the use of the indicator "e" - the internal rate of efficiency, which corresponds to the percentage of a Bank loan, in which the Bank's loan for energy-saving measures can be repaid over the period of implementation of energy-saving measures. Also, this method does not reflect the entire set of economic, technical, organizational, environmental, and production effects. Changes in profit over the years and the amount of the liquidation value are not taken into account. 


\section{Criteria for selecting energy saving investment projects in an agricultural enterprise}

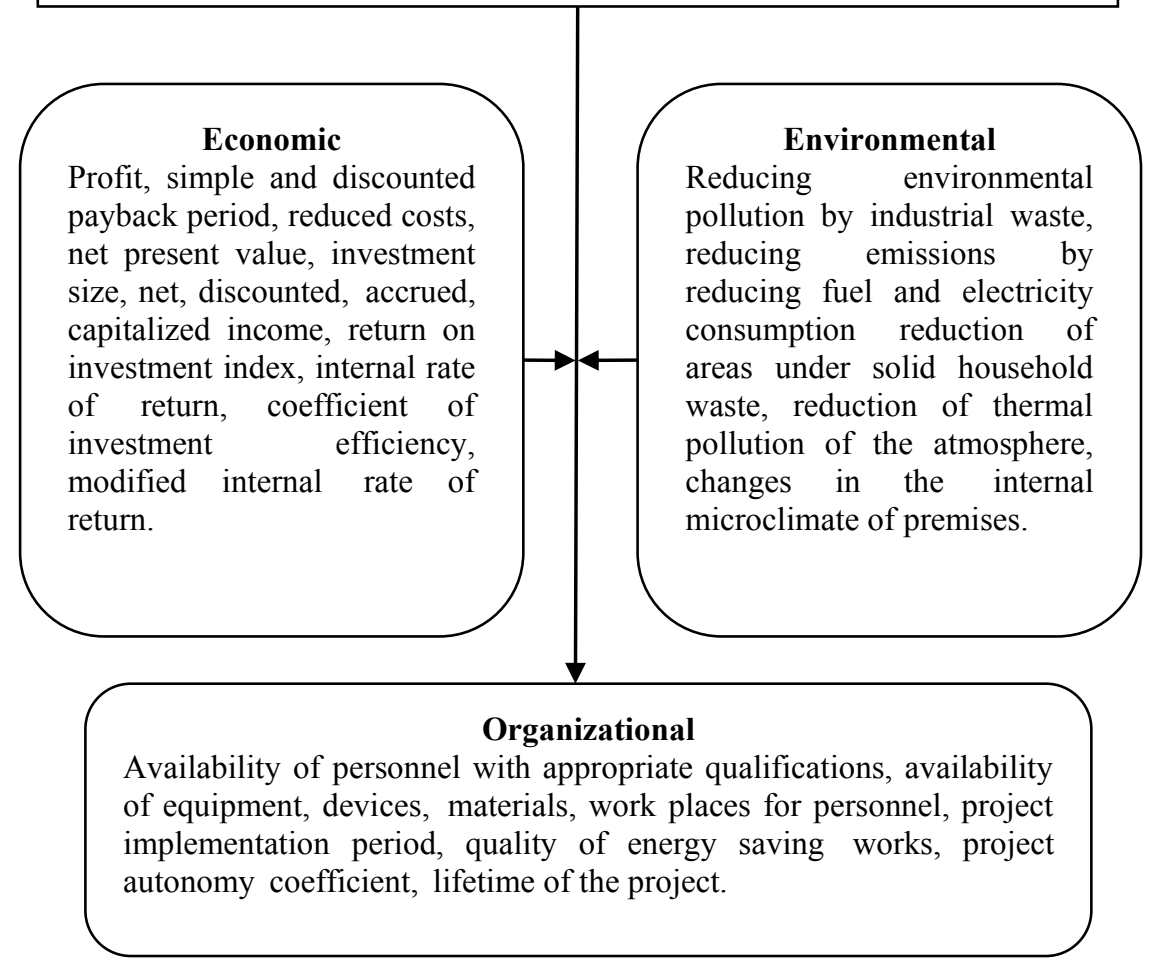

Fig.4 - Selection criteria for energy saving investment projects in agricultural enterprises

In [19], the discounted payback period is proposed as the optimal criterion the period for which the amount of net profit and depreciation will reach the value of the discounted initial investment. The main advantages of this method, according to the author, are its simplicity and direct characterization of the risks of investing funds. The discounted payback period is determined from the equation:

$$
\sum_{t=0}^{T} \frac{\Delta \Pi_{t}}{(1+E)^{t}}=0
$$

where $E$ is the discount rate;

$\Delta \Pi_{t}$ is the increase of profit due to implementation of energy saving measures. 
To determine the effectiveness of investment funds, the service life of the investment object is compared with the resulting payback period. The shorter the discounted payback period, the lower the risks for the investor and the higher the liquidity of the invested funds. The principle of evaluating the effectiveness of investment on the reduced costs, proposed in [29], is to minimize the reduced costs and use the coefficient of relative efficiency of capital investments, the value of which is unknown:

$$
\Pi_{t}=\mathrm{C}_{\mathrm{i}}+\mathrm{E} \times \mathrm{K}_{\mathrm{i}} \rightarrow \min ,
$$

The authors [20] and [21] propose a comprehensive approach to the issue of economic evaluation of energy saving measures based on the theory of fuzzy logic. The combination of qualitative and quantitative characteristics of the project with the help of expert statements allows you to cover a wide range of factors that influence the decision to invest in the project. This technique requires a thorough study of expert information and should be used for analysis and comparison of complex multi-variant projects.

In [22], the main criteria for evaluating the economic efficiency and risks of energy saving investments are to use the net current effect of the investment project (NPV) and the modified internal rate of return of the investment project (IRR). It is proposed to evaluate the efficiency of investments in the formation of cash flow as a result of energy-saving measures by evaluating the energy intensity of one hryvnia of products for certain types of energy resources:

$$
R=\sum_{j=1}^{m}\left(e_{0 j}-e_{1 j}\right) \times Q_{1} \times P_{j}
$$

where $R$ is the main results from the implementation of investments, $\mathrm{UAH}$;

$m$ is the number of types of energy resources, the volume of consumption of which changes from the implementation of the event;

$e_{0 j}, e_{1 j}$ are energy intensity of $1 \mathrm{UAH}$ of produced products for the $\mathrm{j}$-th type of energy resource, respectively, before and after the implementation of the event, NAT units / UAH;

$Q_{1}$ is the volume of products produced in value terms after the implementation of the event, UAH;

$P_{j}$ is unit price of the $\mathrm{j}$-th type of energy resource, $\mathrm{UAH}$.

A comprehensive assessment of the economic efficiency of energy-saving projects is based on comparing the following characteristics of the project: nondiscount income, income with growth (capitalization) and discount income, while calculating the corresponding payback periods. This method is based on the recommendations of the "Association of engineers for ventilation, heating, air conditioning and heat supply " [23] and will allow you to simultaneously consider 
all possible investment options and choose the most optimal one. The discounted income from the energy-saving project is determined from the dependence (7), and the capitalized (accrued) income is determined from the equation (8) [23]:

$$
\begin{aligned}
& D D=D \times\left[1-(1+r)^{T c l}\right] / r, \\
& N D-D \times\left[(1+r)^{T c l}-1\right] / r,
\end{aligned}
$$

where $N D$ - capitalized (accrued) income;

$D D$ is the present value;

$D$ is the annual income;

$r$ is the discount rate.

At the same time, net present income $(N P V)$, simple payback period $\left(T_{0}\right)$ and profitability index $(P I)$ are calculated:

$$
\begin{gathered}
N P V=D D-K, \\
T_{0}=K / D, \\
P I=D D / K,
\end{gathered}
$$

where $K$ - necessary investment in the project.

Preliminary analysis of investment performance should be carried out by comparing the NPV criteria, a project that will have this criterion larger and more acceptable for implementation. When comparing a set of alternative projects with each other, it is necessary to use the additive NPV property [18]:

$$
N P V(A+B)=N P V(A)+N P V(B) .
$$

Another criterion widely used in the practice of comparing investment projects-the internal rate of return on investment (IRR), does not have such properties [18]:

$$
\operatorname{IRR}(A+B) \neq \operatorname{IRR}(A)+\operatorname{IRR}(B)
$$

In addition to the criteria for evaluating investment processes, models are used that can be classified as follows: stochastic model; tabular information models; static information models; dynamic information models; network information models; quantum network model; fuzzy models; models based on neural networks. Economic methods for analyzing investment projects include: the method for analyzing the sensitivity of influence, the method for analyzing development scenarios, the Monte Carlo method, the decision tree method, and others.

The method of influence sensitivity analysis is one of the most common in the economic analysis of investments. It consists of a comparative analysis of the impact of various factors on the key indicator. NVP I IRR are most often used as key indicators. After selecting a set of factors of influence and the limits of their 
variation, the value of the key indicator is calculated. The final step is to plot the sensitivity graph. The use of investment efficiency analysis methods based on the discounting principle has a number of disadvantages [24]:

- spectral complexity and accuracy of calculations by the specified method;

- artificially underestimating the real effectiveness and value of the project;

- sharp depreciation of future receipts of funds in comparison with the receipts of money in the coming years;

- there is no accounting for the impact of additional income from previous years' profits on the total income of future periods and, as a result, an underestimation of the effectiveness of investment in General.

To overcome these disadvantages of the discounting method, the author suggests using the indicator of the full economic result, which is determined according to the equation [24]:

$$
\begin{aligned}
\mathrm{P} R_{j} & =\sum_{t=1}^{T_{j}} \sum_{k=1}^{K_{i}} \sum_{i=1}^{I}\left[\left(D_{i t}-Z_{i t}\right)-N l_{i t}\right] \times\left(1-p_{t k}\right)+\sum_{t=1}^{T_{j}} \sum_{k=1}^{K_{1}} D P_{k t}+S_{t}- \\
& -\sum_{t=1}^{T_{j}} I_{t}
\end{aligned}
$$

where $\mathrm{P} R_{j}$ is the full economic result of the $\mathrm{j}$-th period;

$D_{i t}$ is the income from the $\mathrm{i}$-th type of project activity in year $\mathrm{t}$;

$Z_{i t}$ is the expenses for the $\mathrm{i}$-th type of activity in year $\mathrm{t}$;

$N l_{i t}$ is the tax payments for the $\mathrm{i}$-th type of activity in year $\mathrm{t}$;

$D P_{k t}$ is the income from investing the company's profits in previous years and received by it in the year $\mathrm{t}$;

$p_{t k}$ is the share of the company's profit directed to the K-th type of investment activity in the year $\mathrm{t}$;

$K t$ is the total number of types of investment activities carried out by the enterprise up to a year t;

$S_{t}$ is the market value of the company in year $t$;

$I_{t}$ is the investment in the project in year $\mathrm{t}$.

This method requires a detailed justification of the possibility of using energy saving measures of enterprises to study the investment efficiency. Using only economic criteria for evaluating investments will not allow you to fully evaluate all the features of energy saving measures. There is a need to study other criteria. A number of limitations and features form the organizational criteria for implementing energy-saving measures. The problem of lack of qualified personnel and the necessary equipment or tools for their work creates organizational restrictions in the choice of energy-saving measures. The daily increasing complexity of the equipment requires specially trained maintenance personnel for high-quality operation. Unskilled use of equipment or materials can negate all advances in energy efficiency. 
No less important is the time factor-the period of implementation of the selected energy saving measures. If the implementation of a certain event requires a lot of time and can negatively affect the company, then such negative consequences should be taken into account either in monetary terms, or by expert means. The term of installation and commissioning should be determined by calculation, for example, building a calendar of installation work Usually events related to the replacement of equipment, installation of energoutilizatoriv or transfer to alternative sources, require a stop of production. Therefore, they must be carried out during periods of the lowest production load, on weekends and repair days.

Similarly, it is necessary to take into account the quality of work carried out with the introduction of energy-saving measures. The quality of installation and commissioning works is directly proportional to the effectiveness of the implementation of measures. Even with the highest quality of equipment and materials, incorrect installation will not lead to the expected result. The quality of work can be characterized by the following criteria: the quality of design work, the quality of installation work, and the quality of commissioning. Errors at any stage lead to reduced performance [7].

There are two ways to assess the quality of work: either with the involvement of third-party specialists who are competent in this area, or during operation, determining the change in energy consumption to a declared level. The first way requires the involvement of specialists who can not always be found, the second way requires a clear separation of energy flows measured from other consumers.

From the point of view of practical use, the best way to control the quality of work is to involve third - party specialists, because after the completion of work on the modernization of production and obtaining negative results, repeated modernization requires a repeated stop of production and new investments. The calculation of the investment payback period should be carried out while determining the life of the project. Comparison of these indicators will allow us to draw additional conclusions about the acceptability of investment. The project lifetime depends on various factors, the main ones being:

- quality of work and equipment;

- availability of qualified personnel for maintenance;

- compliance with installation and operation technology;

- period of physical and moral wear and tear.

Estimation of the life cycle duration of an energy saving measure with equal weight coefficients of estimates is carried out according to the equation [24]:

$$
K=\frac{1}{n} \times \sum_{i=1}^{n} \sum_{j=1}^{m}\left(\frac{M_{i, j}}{n}\right) .
$$

The resulting lifetime of the project is compared with the payback period of the project and conclusions are drawn about the attractiveness of such an energysaving event. There may be a situation when the life of the project calculated by 
experts will be significantly less than declared in the technical documentation, and investing in such an event will only make sense if the received income is capitalized, or it will not pay off at all.

The project autonomy coefficient will be defined as the total value of financial and intellectual autonomy. Under financial autonomy, we will understand the ratio of own funds to attracted funds, and under intellectual autonomy - the ratio of the attracted's own intellectual resource (developed by the author):

$$
A=A_{f}+A_{r}=\frac{Z_{v}}{Z_{z}}+\frac{I_{v}}{I_{z}},
$$

where $A_{f}$ and $A_{r}$ are financial and intellectual autonomy;

$Z_{v}$ and $Z_{z}$ are accordingly, its own and attracted funds;

$I_{v}$ and $I_{z}$ are accordingly, own and attracted intellectual resources.

Autonomy coefficients allow you to give preference to alternative projects with equal qualities of other characteristics. It is necessary to try to get as Autonomous a project as possible, so that you do not feel either financial or intellectual dependence. The main directions of technical focus on energy saving can be classified as follows:

- elimination of leaks of heat, water, air and energy resources;

- increasing the thermal resistance of the thermal insulation shell of buildings and structures;

- heat recovery from engineering networks and production equipment;

- replacement of technological equipment or its modernization for less energy consumption;

- optimization of modes and methods of operation;

- use of alternative energy sources and secondary sources;

- diversification and optimization of energy supply.

Simultaneously with the implementation of these directions, it is necessary to check the compliance of the proposed measures with regulatory requirements: whether there are violations of state building codes, state standards, sanitary standards, fire regulations, and so on. Elimination of leaks of heat energy, water, air resources is a priority. After a detailed survey of the building, places with damaged thermal insulation, piped pipes of the heat network and water supply system, uninsulated inputs of engineering networks, there are no check valves, equipment that operates at excessive capacity, and other sources of direct loss of heat, electricity and water are determined.

Also, in places of direct losses, there are contaminated translucent fences that do not pass the necessary amount of light, heat exchange equipment whose surfaces are covered with a layer of scale, and others.

The priority set of works is low-cost measures to eliminate direct losses in setting up production, which is based on existing technologies and equipment to a 
certain level resource consumption without significant and obvious losses Elimination of leaks of heat, water, air does not require replacement of equipment, technologies and materials, but only allows you to achieve the maximum possible level of resource savings due to minor repairs at the existing level of physical and moral wear and tear.

Measures related to the utilization of heat from engineering networks and production equipment are characterized by the efficiency of utilization - the ratio of temperatures or enthalpy of the mass carrier (water, air, steam) before and after passing through the heat exchanger.

Replacing equipment with less energy-intensive equipment requires detailed justification. From the point of view of technical criteria, the main indicator that characterizes the advantages of new equipment over existing ones is the specific consumption of heat or electricity per unit of time or per unit of output. The main criterion for implementing such an event is to achieve energy consumption levels in accordance with existing technological standards.

Alternative energy sources must meet the technical characteristics of the primary energy carriers that they replace. Usually, such sources have lower quality parameters than traditional energy carriers, so replacement should occur under the condition of full compensation for heat or electricity.

Technical limitations of alternative sources may be the features of energyconsuming installations installed in production. Hot water from solar collectors is produced unevenly, and its temperature depends on the time of year and cloud conditions, so it can not be used directly for production without heat accumulators. If the implementation of an event requires significant transformations, it is necessary to check the technical feasibility of implementation.

Special attention should be paid to the quality of the equipment and materials offered. Given the trends of recent years, when the market was filled with low-quality fakes of world brands, and a significant difference in cost between the same type of products from different manufacturers, the problem of technical quality becomes significant. Especially the impact of production quality and adaptation to the conditions of use in Ukraine is felt on complex energy-saving equipment: heat pumps, heat reclaimers, refrigeration units, fans, boilers and other equipment. Only highly professional experts can perform a qualitative assessment of the material or equipment when products are declared to be of high quality.

Analysis by production criteria includes a comparison of measures based on the need to make changes in the production process and the degree of processing of raw materials and the final quality of the product. If a highly efficient energysaving project requires a radical modernization of production, then the capital cost of its implementation must be taken into account and the cost of modernization.

An equally important aspect is the impact of new equipment, technologies or organizational measures on the quality of production products. At the present stage of competition between enterprises, it is unacceptable to allow product 
quality to deteriorate. Increasing energy efficiency is usually accompanied by an increase in the processing depth of primary raw materials.

If reducing energy consumption usually leads to a reduction in the environmental burden on the environment, often ill-considered measures lead to a deterioration of the indoor microclimate of premises. Sealed Windows, insulated walls lead to a complete lack of ventilation in the room. Opening in microventilation mode can partially correct the situation if there are normal environmental conditions outside the window. Unregulated intake of dirty and cold outdoor air can negate all the benefits of implemented measures. Non-cleaning of premises leads to an increase in the concentration of carbon dioxide in the room, which causes allergic and cardiovascular diseases, diseases of the pulmonary system and kidneys.

Especially dangerous is the sealing of basements and first floors. This is due to the accumulation of radioactive radon gas in the premises [18].

The issue of energy saving for the development of agricultural enterprises occupies an important place. The link between energy saving and enterprise development is shown in the significant impact of the component of the cost of energy resources on the cost of products.

Energy saving can affect the increase of the enterprise's potential, the improvement of product quality, the ability to counteract negative manifestations of the environment, and the improvement of environmental friendliness of production. For this purpose, there is a need to determine the state of the modern energy market and energy saving in it, to identify trends and dynamics of consumption and production of primary energy carriers and to determine the potential for energy saving.

Only after a detailed analysis of the above set of criteria, a conclusion is made about the acceptability of a certain set of energy-saving measures for a particular enterprise. A significant number of these criteria can only be evaluated by an expert with the assignment of a qualitative characteristic on a certain conditional scale.

The task arises to investigate the features of investment in energy saving measures and develop an intelligent decision support system for finding optimal ways to manage the energy saving potential of agricultural enterprises.

As a conclusion, we can say that the experience of Ukraine on energy saving, in comparison with European countries, is less and not so widespread. Ukraine has only recently embarked on a massive energy saving policy among enterprises. Projects and laws on energy saving have just started to be implemented at the legislative level. Energy saving is one of the factors of agricultural development, because it not only saves fuel and energy resources, but also encourages the population to work on renewable-alternative energy sources, the use of which will not only bring great benefits and profit, but also will not pollute the environment, will carry environmental friendliness and profit. 


\section{Global experience in managing project risks and approaches in energy-saving projects}

The world Energy Council (WEC) annually calculates the energy sustainability index of countries. The index is assigned based on a comparative analysis of the energy situation in a particular country, based on three indicators: "energy security", "energy capacity", "environmental sustainability", taking into account a balanced approach between the relevant indicators.

Energy security refers to effective management, energy supplies from internal and external sources, energy market diversification, reliability of energy infrastructure, and the level of satisfaction of current and future demand for energy resources.

Energy capacity is the level of fuel and energy resources expenditures per unit of GDP, as well as the availability and accessibility of consumers to energy resources.

Environmental sustainability describes the efficiency of using energy resources and the share of renewable energy sources in the total volume.

Business efficiency is based on the balance of income and production costs, which necessarily include the cost of energy consumed - heat, electricity or other. And the lower these costs, the more efficient the business is. The lower the energy consumption, the higher the energy efficiency. Energy saving in any sphere is reduced to rational use of energy, reducing wasteful losses.

To measure energy efficiency, first count how much energy is produced in each country in a given time period. To do this, use the conventional universal unit of measurement of various types of energy toe (ton of oil equivalent), or the amount of energy that is generated from the combustion of one ton of crude oil. The lower the ratio of energy use to GDP, the more efficiently and economically a country uses its energy resources.

The top ten countries on this list are Colombia, Great Britain, Italy, Venezuela, Romania, Portugal, and Spain. These countries have the lowest level of energy use in the world. At the bottom of this list are Ukraine, Russia, Taiwan, Uzbekistan, South Africa, and Kazakhstan. These are the countries that use energy more than others.

Energy efficiency is studied by the independent research and analytical company Energydata, founded in 1991. Analysts of the company conduct a lot of research, one of the most famous is the Statistical Yearbook of world energy. It provides data on the production of gas, oil, electricity and other types of energy and the level of their use in different countries [25].

With an index of 0.246 , our country is the last in the world in terms of energy efficiency. In neighboring Poland, this level is 0.095 , in Romania there is 0.069 , in the Czech Republic there is 0.115 . The global average is 0.116. Data on these indicators are presented in table 2. 
Table 2 - indicator of the level of energy efficiency of countries at the end of 2019

\begin{tabular}{|c|c|c|}
\hline A country & Indicator & The average rate in the world \\
\hline Poland & 0,095 & \multirow{2}{*}{0,116} \\
\hline Romania & 0,069 & \\
\hline Czech & 0,115 & \\
\hline Ukraine & 0,246 & \\
\hline
\end{tabular}

According to the Oxford Institute for Energy Studies, the level of energy consumption in terms of GDP in Ukraine is 3.8 times higher than the average in Europe [26].

This is mainly due to the low level of investment in the development of energy-efficient technologies. Usually, a Ukrainian household consumes $32 \%$ more energy per square meter of living space (with the same duration of the heating season). If Ukraine reached the European average for these categories, the use of gas for the population and heating of premises would be less by $61 \%$, according to analysts of the Oxford Institute for Energy Studies. Thermal modernization of residential buildings, the monetization of subsidies is only the first and obvious action. There may be many more.

Last time, we can see the trend that every year more and more energy consumption based on renewable energy is gaining popularity. In particular, energy consumption from biofuels and waste increased by 2102 thousand tons $n$. e. to 3049 thousand tons n. e.in 2017. Also, consumption from wind and solar energy increased, as in 2015 it was at the level of 134 thousand tons n. e., and in 2017 it was already 149 thousand tons n. e.

Implementation of the energy saving strategy at the enterprise takes place at the level of production divisions and administrative centers using a number of management methods (economic, organizational, socio-psychological, etc.) for energy saving and energy consumption at the enterprise. Implementation of energy saving occurs through the creation of an appropriate structural division, or a group of employees responsible for energy conservation in the enterprise. Therefore, the introduction of an energy saving strategy in industrial enterprises is appropriate as it is one of the key factors in increasing their profitability.

Depending on the success in each direction, the country is assigned a rating from $\mathrm{A}$ to $\mathrm{D}$ in alphabetical order, where each letter is assigned a scale from 0 to 10 :

$\mathrm{A}$ is the highest result corresponds to a scale from 8.01 to 10.00 ;

$\mathrm{B}$ is the average result corresponds to a scale from 5.01 to 8.00 ;

$\mathrm{C}$ is below average, corresponds to a scale from 2.51 to 5.00 ;

$\mathrm{D}$ is the lowest, unsatisfactory result corresponds to a scale from 0 to 2.5 .

Behind this ranking, the following countries have the best result in 2018: Switzerland, Sweden, Norway, Great Britain, Austria, Denmark, Canada, France, Finland, the Netherlands and the United States (table 3). 
Table 3 -Countries' energy saving Policies

\begin{tabular}{|c|c|}
\hline A country & Results in the field of energy saving \\
\hline 1 & 2 \\
\hline USA & $\begin{array}{l}\text { An example is the financial program "Energy Efficient business", } \\
\text { which is successfully operating in the state of Connecticut } \\
\text { (USA). Under its terms, business owners who decide to improve } \\
\text { the energy efficiency of their own enterprise can expect a } \\
\text { significant discount from energy supply companies, as well as an } \\
\text { interest-free loan for the introduction of new technologies. In } \\
\text { General, energy conservation issues in the United States are } \\
\text { resolved on a strict, mandatory basis. The user of energy } \\
\text { resources is deprived of the right to choose or not to choose the } \\
\text { path of energy-efficient management. The consumer has two } \\
\text { options for legitimate behavior: either they comply with the } \\
\text { requirements of Federal and local state authorities for energy } \\
\text { conservation, or they pay fines for failure to comply with these } \\
\text { requirements. Back in 1992, the Federal energy policy Act of } \\
1992 \text { was adopted, which defined the main areas of energy } \\
\text { conservation in the United States of America. }\end{array}$ \\
\hline Denmark & $\begin{array}{l}\text { The country has invested heavily in efficient energy solutions and } \\
\text { renewable energy sources. At the same time, tax breaks have made } \\
\text { it more attractive for businesses to focus on alternative and } \\
\text { optimally efficient energy solutions. For example, the Danish } \\
\text { energy Agency enters into a three-year contract with energy- } \\
\text { intensive industrial enterprises. For its part, the Agency provides a } \\
\text { discount on the payment of energy tax (applies to electric energy } \\
\text { for heavy industrial processes and for space heating). On the other } \\
\text { hand, industrial enterprises are obliged to implement a certified } \\
\text { energy management system, i.e. an energy management system, in } \\
\text { accordance with the agreement, as well as implement energy } \\
\text { efficiency projects that have a payback period of less than four } \\
\text { years. If industrial enterprises do not comply with the terms of the } \\
\text { agreement, it is canceled, and the company is obliged to repay the } \\
\text { tax discount for the duration of the agreement. Industrial } \\
\text { enterprises also receive financial support for the purchase of } \\
\text { energy efficient equipment. }\end{array}$ \\
\hline
\end{tabular}


Continuation of the table 3

\begin{tabular}{|c|c|}
\hline 1 & 2 \\
\hline Finland & $\begin{array}{l}\text { The Finnish government is developing additional incentives for } \\
\text { enterprises to improve their energy efficiency: subsidies for the } \\
\text { purchase of new technologies, tax incentives. All Finnish enterprises } \\
\text { are included in the waste recycling system. The focus on energy } \\
\text { efficiency and environmental friendliness has allowed Finland to } \\
\text { become one of the leaders in the production and export of clean } \\
\text { technologies and breakthrough innovative solutions. The expansion } \\
\text { of energy audit recommendations for municipalities and enterprises } \\
\text { is positive on a national scale. In addition, voluntary agreements on } \\
\text { energy efficiency in trade and industry are expanding across } \\
\text { individual sectors of the economy and companies. A number of } \\
\text { programs have been introduced that provide financial support for } \\
\text { energy efficiency. } \\
\text { There is even a merger of municipalities to implement the plans, } \\
\text { since smaller municipalities have fewer opportunities in the field of } \\
\text { human resources and in financial terms, and with the merger there is } \\
\text { enough own funding for the implementation of rather expensive } \\
\text { energy efficiency projects. }\end{array}$ \\
\hline Norway & $\begin{array}{l}\text { Norway has liberalized the electricity market, which has declared } \\
\text { the main principle of energy efficiency - high electricity prices, } \\
\text { which reflect its real cost, can make investments in the energy } \\
\text { efficiency sector profitable, while low prices make the } \\
\text { implementation of most programs in this area impossible. Thus, the } \\
\text { refusal at the state level to lower the price of electricity better } \\
\text { encourages owners to implement energy efficiency in enterprises. } \\
\text { Otherwise, businesses are not able to compete in the market, which } \\
\text { eventually leads to their bankruptcy. Norway's energy efficiency } \\
\text { policy is strict, but, as practice shows, effective. }\end{array}$ \\
\hline Sweden & $\begin{array}{l}\text { Sweden has a clear system of control over the use of energy } \\
\text { resources. This can be seen in mandatory declarations for } \\
\text { enterprises with the use of energy resources, energy certificates of } \\
\text { buildings, in the labeling of goods and even in the labeling of food. } \\
\text { In addition, officials actively use economic incentives to promote } \\
\text { the use of alternative energy sources. There is an exemption for a } \\
\text { period of five years from the energy tax, the provision of state } \\
\text { subsidies for the reconstruction of old buildings (replacement of } \\
\text { boilers, insulation, etc.), simplified obtaining permits for the } \\
\text { construction of wind farms. }\end{array}$ \\
\hline
\end{tabular}


Continuation of the table 3

\begin{tabular}{|l|l|}
\hline 1 & \multicolumn{1}{|c|}{2} \\
\hline Germany & $\begin{array}{l}\text { German legislation and regulations state that banks and large } \\
\text { corporations Finance the implementation of energy saving, not } \\
\text { the state. Over the past decades, the country has tested the use of } \\
\text { a Contracting tool (energy service contracts) as an element of } \\
\text { public - private partnership. It assumes that in conditions when } \\
\text { the owners of the enterprise are financially unable or do not have } \\
\text { sufficient information to implement an energy-efficient policy at } \\
\text { the enterprise, the solution of this task is assumed by the } \\
\text { contractor, who conducts energy audits of structural divisions of } \\
\text { the enterprise, assesses the efficiency of the production process at } \\
\text { the enterprise in accordance with established standards. Further, } \\
\text { based on the received data, the contractor makes the appropriate } \\
\text { decision and ensures the implementation of the planned action } \\
\text { plan in the direction of energy efficiency and assumes the project } \\
\text { financing }\end{array}$ \\
\hline Netherlands \\
$\begin{array}{l}\text { In the Netherlands, a regulatory energy tax was introduced in } \\
\text { 1996 to provide financial incentives to save energy and reduce } \\
\text { carbon dioxide emissions. Regarding depreciation policy, in the } \\
\text { Netherlands there is a free depreciation scheme for environmental } \\
\text { investments (the Vamil list). It provides entrepreneurs with } \\
\text { financial advantages, since it allows accelerated depreciation of } \\
\text { certain equipment included in the environmental list for tax } \\
\text { purposes (Vamil list), which reduces the company's tax payments } \\
\text { and its deductions from profits in the first years after the } \\
\text { investment and improves the company's position in terms of } \\
\text { receiving money. The energy investment benefits Scheme (EIA) } \\
\text { offers tax incentives for investments in energy-saving } \\
\text { technologies and technologies for generating energy from } \\
\text { renewable sources. If a particular equipment is included in the } \\
\text { Vamil list, up to 52\% of investment expenses can be deducted } \\
\text { from profit taxation. }\end{array}$ \\
\hline
\end{tabular}

World experience shows that effective measures in the direction of energy efficiency can reduce the growth of national demand for fuel and energy resources, which will reduce the import of fuel and energy resources and, consequently, remove the energy problems of countries with economies in transition. At the same time, a well-developed energy strategy of the country and effective projects of international cooperation in the field of energy efficiency will contribute to improving energy efficiency, economic development, environmental and national security of the country. 
Taking into account the world experience, the International energy Agency identifies the following mechanisms of energy efficiency policy at the state level: pricing; regulatory and controlling; financial and fiscal incentives; information mechanisms; technological, commercial and financial development [27]. This classification is objective for evaluating the energy efficiency of industrial enterprises in Ukraine, subject to appropriate adaptation of mechanisms.

Having conducted the analysis, we will try to identify the following specific mechanisms of energy efficiency policy for industrial enterprises in Ukraine:

- prices that encourage industrial enterprises to search for new ways and methods to increase the level of efficiency of the use of fuel and energy resources;

- regulatory, including national and international standards, certification, as well as compliance with mandatory and recommendatory legislation;

- controlling bodies that provide for monitoring compliance with legislation and the company's obligations in the direction of energy efficiency, and in exceptional situations - the imposition of penalties;

- information that combines sources of information about ways and methods to improve energy efficiency in industrial enterprises;

- motivational programs that provide financial and fiscal incentives, soft loans, technical assistance, and so on.

Compare specific mechanisms (pricing, regulatory, regulatory, informational and motivational) managing energy efficiency in industrial enterprises on the basis of the analysis of best practices in industrialized countries such as: USA, Denmark, Finland, Norway, Sweden, Germany, the Netherlands and the experience of Ukraine, which are presented in table 4.

Table 4 - Systematization of energy efficiency policy elements for industrial enterprises

\begin{tabular}{|l|c|c|c|c|c|}
\hline \multirow{2}{*}{ A country } & \multicolumn{5}{|c|}{ Elements of an energy efficiency policy } \\
\cline { 2 - 6 } & Price & Regulatory & Supervisory & Informational & Motivational \\
\hline 1. USA & & + & + & + & + \\
\hline 2. Denmark & & & & + & + \\
\hline 3. Finland & & & & + & + \\
\hline 4. Norway & + & + & + & & + \\
\hline 5. Sweden & & + & & & + \\
\hline 6. Germany & & & & + & + \\
\hline 7. Netherlands & & & & & + \\
\hline 8. Ukraine & & + & + & & + \\
\hline
\end{tabular}


The energy policy of the EU and the leading countries of the world in the direction of energy efficiency is proving to be effective and should therefore be adopted by domestic specialists. Implementation of energy efficiency programs in Ukraine requires changes in the algorithm of work in the organizational, financial, legal and information spheres.

A study of world experience in energy efficiency policy has found that an effective energy saving policy is based on three main principles: encouraging energy savings, forcing energy efficiency, and providing educational programs in the direction of efficiency. The main element of the mechanism for implementing energy efficiency in domestic enterprises is the transition to public-private partnership, which will provide the necessary financial resources and provide the necessary dynamics to the process.

\section{References:}

1. Tsikalyuk Yu.O. Problems of economy and rational use of energy resources in agro-industrial complex [Electronic resource]. - Access mode: http://sophus.at.ua/publ/2015_10_30_kampodilsk/sekcija_section_1_2015_10_30/ problemi_ekonomiji_i_racionalnogo_vikoristannja_energoresursiv_v_apk/102-1$0-1541$ [in Ukrainian].

2. Medvedovsky O.K., Ivanenko P.I. (1998). Energy analysis of intensive technologies in agricultural production. - Kiev. -208 p. [in Ukrainian].

3. Teslyuk G.V., Kuzmenko O.F., Stepura I.S. Ways of rational energy saving in agriculture [Electronic resource]. - Access mode: http://sophus.at.ua/publ/2015_10_30_kampodilsk/sekcija_section_1_2015_10_30/s hljakhi_racionalnogo_energozberezhennja_v_silskomu_gospodarstvi/102-1-01539. [in Ukrainian].

4. Grishko V.V., Perebyinis V.I., Slavery V.M. (1996). Energy saving in agriculture (economy, organization, management), Poltava, 280 p. [in Ukrainian].

5. The use of energy-saving technologies in EU countries: experience for Ukraine [Electronic resource]. - Access mode: https://niss.gov.ua/doslidzhennya/nacionalna-bezpeka/vikoristannyaenergozberigayuchikh-tekhnologiy-v-krainakh-es [in Ukrainian].

6. Energy saving as one of the main directions of the new EU energy policy [Electronic resource]. http://www.nas.gov.ua/siaz/Ways_of_development_of_Ukrainian_science/article/1 4016.3.1.001.pdf. [in Ukrainian].

7. Experience of energy saving of individual EU countries [Electronic resource]. - Access mode: http://www.nas.gov.ua/siaz/Ways_of_development_of_Ukrainian_science/article/1 4026.3.1.002.pdf 
8. European experience of institutional relations of executive bodies responsible for the formation and implementation of state policy in the field of energy efficiency / energy saving and / or development of renewable energy sources [Electronic resource]. - Access mode: http://euinfocenter.rada.gov.ua/uploads/documents/28964.pdf.

9. Conceba S.M. Energy saving technologies in Ukraine: economic effect and prospects of implementation [Electronic resource]. - Access mode: http://lib.udau.edu.ua/bitstream/123456789/666/1/\%D0\%9A\%D0\%BE\%D0\%BD $\% \mathrm{D} 1 \% 86 \% \mathrm{D} 0 \% \mathrm{~B} 5 \% \mathrm{D} 0 \% \mathrm{~B} 1 \% \mathrm{D} 0 \% \mathrm{~B} 0$. pdf. [in Ukrainian].

10. Bozhiday I.I. Analysis of the agricultural sector of Ukraine [Electronic resource]. Access mode: http://www.economy.nayka.com.ua/pdf/9_2018/152.pdf. [in Ukrainian].

11. State Statistics Service [Electronic resource]. - Access mode: http://www.ukrstat.gov.ua/.[in Ukrainian].

12. Pogorelov Yu.S.(2016). Changes in the potential of the enterprise as the driving force of its development. Ekonomika ta rehion, vol. 2, pp. 59 - 66. Access mode: http://nbuv.gov.ua/UJRN/econrig_2016_2_11.

13. Energy strategy of Ukraine for the period up to 2030 [Electronic resource]. - Access mode: https://de.com.ua/uploads/0/1703EnergyStratagy2030.pdf.

14. Analysis of energy efficiency in developed foreign countries and dependence on their imports [Electronic resource]. - Access mode: https://ua.energy/wp-content/uploads/2018/01/1.-Efektyvnist_energ_resursiv.pdf. [in Ukrainian].

15. Energy efficiency in the regional dimension. Problems and prospects [Electronic resource]. - Access mode: https://niss.gov.ua/sites/default/files/201408/energoefekt-b40dc.pdf. [in Ukrainian].

16. Djedzhula V.V. (2013). Formation of organizational and economic mechanism improvement of energy efficiency of the industrial enterprises. Ekonomichnyi analiz: zb. nauk. prats, vol.12 (3), pp. 116-118. [in Ukrainian].

17. Mayorova T.V., Maksimovich V.I., Urvantseva S.V. (2012). Investing: workshop, Kiev, 577 p. [in Ukrainian].

18. Djedjula V.V. (2014). Investment in energy saving actions of industrial enterprises, Actual problems of economic, vol. 1 (151), pp. 163-169. [in Ukrainian].

19. Belova E.M. (2006). Central air conditioning systems in buildings. Moscow -640 p. [in Ukrainian].

20. Ratushnyak O.G. (2010). Management of the content of innovative projects of thermal modernization of buildings: monograph, Vinnytsia, 128 p. [in Ukrainian].

21. Serdyuk T.V. (2005). Organizational and economic mechanism of energy saving in industry: monograph, Vinnytsia, 154 p. [in Ukrainian]. 
22. Yefimova G.V. (2002). Estimation of economic efficiency of investments in energy saving in the industry (on an example of mechanical engineering): dis. Cand. econ. Science: special. 08.07.01 "Economics of Industry" / NAS of Ukraine; Inst of Market Problems and Economic and Environmental Research, Odessa, $21 \mathrm{P}$.

23. Gorbachenko S.A., Karpov V.A. (2013). Analysis of business projects, Odessa, $241 \mathrm{p}$.

24. Samoilenko I.O. (2019). Summary of lectures on the subject "Investment Management" (for master's students of all forms of education specialty 073 - Management), Kharkiv, 84 p.

25. The price of the state [Electronic resource]. - Access mode: https://www.facebook.com/cost.ukraine/photos/p.2590424431038948/2590424431 $038948 /$ ?type $=1 \&$ theater.

26. Experience of EU countries in improving energy efficiency, energy audit and energy management in energy saving in the economy [Electronic resource]. - Access mode: https://ua.energy/wpcontent/uploads/2018/01/Pidvyshhennya-energoefektyvnosti-v-YES.pdf.

27. Skril V.V. (2020). The system of financial and economic support of energy saving measures in Ukraine and the EU. Bulletin of ZhSTU: Economics, Management and Administration, vol. 1, pp.146-153. 